\section{Nucleic Acids in Immunology}

Proceedings of a Symposium held at the Institute of Microbiology of Rutgers, The State University. Edited by O. J. Plescia and W. Braun. Springer-Verlag 1968. Bound volume with cover; $16 \times 24 \mathrm{~cm}$; XVII +724 pages; 195 black-and-white illustrations and 1 color plate. Price DM 88 (US $\$ 22.00$ ).

This book has the advantage, for immunologists, geneticists and allied scientists, of presenting the subject in the form of the proceedings of a Symposium. This means that papers on individual subjects are followed by discussions in which the representatives of the various branches of research express their opinions, doubts or hypotheses, thus often voicing several questions that the reader might otherwise find unanswered.

The subject itself is interesting for many scientists, and this book will probably remain a landmark on the road leading to the correct interpretation of many life processes involved in the metabolism of nucleic acids and in the mysterious steps that link antigens and haptens to immune responses (or non-responses).

Several chapters will be extremely useful for teachers at various levels, while the experiments reported in others will be valued by research personnel.

We advise potential readers not to rush too quickly through this book.

\section{Milani-Comparettit}

\section{Handbook of Congenital Malformations}

(Manuale delle Malformazioni Congenite)

Edito da A. Rubin. W. B. Saunders Co. London 1967. Volume di $16 \times 24 \mathrm{~cm}$; XIII +398 pagine; 34 illustrazioni in bianco e nero; glossario; indice. Prezzo £ 519 s. (\$15.00 circa).

Il manuale è diviso in 14 capitoli in ciascuno dei quali sono trattate in maniera schematica, ma sufficiente, le malformazioni dei singoli sistemi o apparati nel seguente ordine: apparato digerente, mammella, sistema car- diovascolare, sistema endocrino, sistema osteomuscolare, sistema nervoso, faccia e bocca, sistema respitatorio, occhio, orecchio, naso-faringe-laringe, pelle e unghie, sistema urogenitale.

Nei singoli capitoli le malformazioni vengono riportate in ordine alfabetico e sinteticamente trattate con uno schema comune che considera la frequenza di manifestazione, le alterazioni associate, l'ereditarietà e le possibilità di trattamento. Sono inoltre riportati i dati bibliografici essenziali.

Il $14^{\circ}$ capitolo è suddiviso in due parti e tratta dell'eziologia, prendendo in considerazione nella prima parte gli agenti infettivi e nella seconda parte gli agenti fisico-chimici capaci di favorire l'evento malformativo.

Un brevissimo glossario completa il manuale.

G. Del Porto

\section{The Genetics of Dermal Ridges}

By Sarah B. Holt (London). A monograph in the series "American Lectures in Living Chemistry " edited by I. N. Kugelmass. Charles C Thomas. Springfield 1968. Bound volume with cover; $17 \times 24 \mathrm{~cm}$; XVIII +196 pages; 45 tables; 63 black-and-white illustrations. Price $\$ 15.75$.

Recent years have witnessed a growing interest in dermatoglyphics, mainly on the part of geneticists and clinicians.

Geneticists have tried to define the limits and the mechanism of the genetic information underlying their determination. The twin method has been widely used in so doing. Conversely, fingerprints having been shown to undergo almost complete (0.95-0.98) genetic conditioning, their analysis has also been applied to the diagnosis of zygosity in twins.

Findings of associations of dermatoglyphic peculiarities with different kinds of diseases, mainly malformations and chromosomal aberrations, have also widely interested both geneticists and clinicians-the latter being especially concerned because of the possibility of find- 
ing in dermatoglyphics a great help for early diagnosis.

Dr. Holt, from the Galton Laboratory in London, has largely contributed in the last twenty years to the progress in dermatoglyphic research, mainly through original investigations centering on the quantitative study and interpretation of fingerprints.

In this book, she has now supplemented her own experience with a general account of dermatoglyphics, mainly from the genetic point of view.

The text is divided into three main sections: (1) an introductory account of dermal ridges, their arrangement on palms and fingers, soles and toes, and their normal variability; (2) a detailed account of the quantitative genetics of dermatoglyphics in normal populations, with special respect to fingerprints, their methods of study (total finger ridge count) and their application to the diagnosis of zygosity in twins; (3) finally, dermatoglyphic peculiarities associated to pathologic conditions.

A number of remarks may be ventured.

First of all, the statement that the total finger ridge count be an inherited metrical trait is not entirely acceptable. Digital dermatoglyphics certainly undergo almost complete genetic conditioning; it would be reasonable, however, to consider that genetic factors, rather than acting at a cumulative level for all ten fingers, underlie single finger quali-quantitative traits. In fact, although total finger ridge counts in MZ twins show a correlation of approximately $0.95-0.98$, single finger values also show remarkably high correlations-slightly lower than those for cumulative values, only on account of their obviously higher random variability.

No account has been given of a large number of conditions in which dermatoglyphic peculiarities have been described: these include schizophrenia, for which thousands of cases have been sofar examined, or important malformative syndromes, such as Brachmann-de Lange syndrome.
Important references are lacking: although Down's syndrome is largely dealt with, no account is given of the fundamental contribution by Beckmann, Gustavson and Norring (1965), defining the possibility of a diagnosis of mongoloidism exclusively based on dermatoglyphic analysis. The same applies to Wendt's original contribution (1955) on the " individuelle Musterwert" for fingerprint studies, and to a large number of sometimes important contributions, especially by nonEnglish scientists. It must be noted, however, that this observation generally applies to any book of this kind, and that it is often impossible, or unfitting, to afford a large number of references.

This book is, nevertheless, highly welcome: in it, Dr. Holt succeeds in filling, at least in part, the gap existing between the publication of Cummins and Midlo's largely known classic in 1943 (reprinted in 1961) and the present status of dermatoglyphic research.

Dr. Holt has to be congratulated on her important work, which deserves the success it will undoubtedly have: geneticists and pediatricians will especially appreciate and welcome it.

\section{P. PArisi}

\section{Essai de Classification des Dysplasies Spondylo- Epiphysaires}

(Saggio di Classificazione delle Displasie Spondilo-Epifisarie)

Di P. Maroteaux, R. Wiedemann, J. Spranger, K. Kozlowski, L. Lenzi. Collana «Monographies de Génétique Médicale ». Simep Editions. Lyon 1968. Volume di $15 \times 24 \mathrm{~cm}$; 95 pagine; 59 illustrazioni in bianco e nero. Prezzo non indicato.

Gli autori, prima di entrare in merito alla classificazione, si preoccupano di delimitare il quadro clinico e porre una definizione precisa della malattia.

Al fine di un inquadramento razionale che prenda in considerazione tutte le sindromi de- 